\title{
Hydraulic characteristics and sediment generation on slope erosion in the Three Gorges Reservoir Area, China
}

\author{
Feng Qian ${ }^{1,2^{*}}$, Dongbin Cheng ${ }^{1}$, Wenfeng Ding ${ }^{1}$, Jiesheng Huang $^{2}$, Jingjun Liu ${ }^{3}$ \\ ${ }^{1}$ Department of Soil and Water Conservation, Changiiang River Scientific Research Institute, Wuhan, Hubei 430015, China. \\ ${ }^{2}$ School of Water Resources and Hydropower Engineering of Wuhan University, Wuhan, Hubei 430010, China. \\ ${ }^{3}$ Wuhan Hydrology and Water Resources Survey Bureau, Wuhan, Hubei 430074, China. \\ * Corresponding author. Tel.: +86 02782926992. Fax: +86-02782926357. E-mail: qianfeng@whu.edu.cn
}

\begin{abstract}
Hydrological processes play important roles in soil erosion processes of the hillslopes. This study was conducted to investigate the hydrological processes and the associated erosional responses on the purple soil slope. Based on a comprehensive survey of the Wangjiaqiao watershed in the Three Gorges Reservoir, four typical slope gradients $\left(5^{\circ}\right.$, $10^{\circ}, 15^{\circ}$ and $\left.20^{\circ}\right)$ were applied to five rainfall intensities $\left(0.6,1.1,1.61,2.12\right.$ and $\left.2.54 \mathrm{~mm} \cdot \mathrm{min}^{-1}\right)$. The results showed that both surface and subsurface runoff varied greatly depending on the rainfall intensity and slope gradient. Surface runoff volume was 48.1 to 280.1 times of that for subsurface runoff. The critical slope gradient was about $10^{\circ}$. The sediment yield rate increased with increases in both rainfall intensity and slope gradient, while the effect of rainfall intensity on the sediment yield rate was greater than slope gradient. There was a good linear relationship between sediment yield rate and Reynolds numbers, flow velocity and stream power, while Froude numbers, Darcy-Weisbach and Manning friction coefficients were not good hydraulic indicators of the sediment yield rate of purple soil erosion. Among the three good indicators $(R e, v$ and $w)$, stream power was the best predictor of sediment yield rate $\left(R^{2}=0.884\right)$. Finally, based on the power regression relationship between sediment yield rate, runoff rate, slope gradient and rainfall intensity, an erosion model was proposed to predict the purple soil erosion $\left(R^{2}=0.897\right)$. The results can help us to understand the relationship between flow hydraulics and sediment generation of slope erosion and offer useful data for the building of erosion model in purple soil.
\end{abstract}

Keywords: Purple soil; Runoff; Flow hydraulics; Sediment; Slope gradient; Rainfall intensity.

\section{INTRODUCTION}

Purple soil is the dominant soil in the Three Gorges Reservoir Area in China. Many reasons, such as shallow and loose soil layer, improper land use and numerous rainstorms, have caused serious soil erosion in the purple soil region, which is a major environmental problem in China (Fu et al., 2011; Peng et al., 2014). Average soil erosion rates in the purple soil region have reached $3400 \mathrm{t} \mathrm{km}^{-2}$ year $^{-1}$, in some areas, even reached $9000 \mathrm{t} \mathrm{km}^{-2}$ year $^{-1}$ (Wen et al., 2005). Such severe soil erosion has caused land degradation and ecological destruction in this region. Therefore, it is essential to understand the mechanisms of soil erosion process in order to accurately predict purple soil loss and implement specific soil and water conservation measures.

Researches indicate that the soil erosion process is influenced by rainfall, overland flow, topography, and soil properties (Fox et al., 1997; Knapen et al., 2008; Liu et al., 2015; Zhang et al., 2007). As soil erosion by rainfall is highly dependent on flow hydraulic properties (flow velocity, flow regime, stream power and hydraulic resistance). These parameters are frequently used in predicting sediment concentration. Zhang et al. (2003) found a linear function between flow velocity and sediment transport. For a given shear stress, detachment rate by shallow flow is primarily associated with flow regime (Nearing and Parker, 1994). Gilley et al. (1985) and Nearing et al. (1997) indicated that stream power was appropriate predictor for soil detachment capacity. The stream power $(w)$ was calculated as follows (Hairsine and Rose, 1992):

$w=\rho g S q$ where, $\rho$ is the density of water $\left(\mathrm{g} \cdot \mathrm{cm}^{-3}\right), \mathrm{g}$ is acceleration of gravity $\left(\mathrm{m} \cdot \mathrm{s}^{-2}\right), S$ is slope gradient $\left(\mathrm{m} \cdot \mathrm{m}^{-1}\right), q$ is the unit discharge of runoff $\left(\mathrm{cm}^{2} \cdot \mathrm{s}^{-1}\right)$. Darcy-Weisbach $(f)$ and Manning friction coefficients $(n)$ are the most often used to characterize hydraulic resistance and can be calculated from Eqs. (2) and (3), respectively:

$$
\begin{aligned}
& f=\frac{8 g h S}{V^{2}} \\
& n=V^{-1} S^{1 / 2} h^{2 / 3}
\end{aligned}
$$

where, $V$ is flow velocity $\left(\mathrm{m} \cdot \mathrm{s}^{-1}\right), h$ is mean flow depth $(\mathrm{m})$. In the WEPP model (Foster et al., 1995), $f$ is the presence of soil surface characteristic. Models such as LISEM (De Roo et al., 1994) and EUROSEM (Morgan et al., 1998) use $n$ to quantify the relationship between flow velocity and geometry in the channel.

A vast number of studies have investigated relationships that describe flow hydraulic properties and sediment detachment. However, these hydraulic properties cannot be measured directly. Consideration for the small scale of the plots, soil erodibility, infiltration and runoff can be measured (Cerdà, 1998; Cerdà et al., 2009). Many studies have investigated that rainfall intensity and slope gradient are the two principal factors that affect the hydrological processes and the associated erosional responses on the slope. (Assouline and Ben-Hur, 2006; Donjadee and Chinnarasri, 2012; Fox and Bryan, 2000). The sediment yielding process depends on the reaction of the soil surface to the erosive stress influenced by rainfall, slope gradient and soil properties (Defersha and Melesse, 2012). According to Julien and Simmons (1985), the relationship of sediment transport 
capacity could be expressed as a power function of slope, discharge and rainfall intensity. Zhang et al. (1998) proposed the equation

$$
D_{i}=K_{i} I Q^{1 / 2} S^{2 / 3}
$$

where $D_{i}$ is the delivery of sediment from interrill areas $\left(\mathrm{kg} \cdot \mathrm{m}^{-2} \cdot \mathrm{s}^{-1}\right), K_{i}$ is the interrill erodibility $\left(\mathrm{kg} \cdot \mathrm{s} \cdot \mathrm{m}^{-4}\right), I$ is the rainfall intensity $\left(\mathrm{mm} \cdot \mathrm{min}^{-1}\right), Q$ is the runoff rate averaged over the entire runoff interval $\left(\mathrm{m} \cdot \mathrm{s}^{-1}\right)$. Another effort was made by Bulygin et al. (2002), who proposed the equation

$$
D_{i}=K_{i} I Q S^{2 / 3}
$$

Although great efforts have been made in improving the model of erosion, there is limited knowledge about the effects of flow hydraulic characteristics on sediment concentration in purple soil. Moreover, most of the previous studies are concerned with hydraulic properties of shallow flow (Zhang et al., 2002) and hydrodynamic characteristics of rill flow on steep slopes (Peng et al., 2015; Wang et al., 2015) and runoff hydraulic characteristics in rill erosion ( $\mathrm{Li}$ et al., 2008; Rafael and Gerard, 2008). But the hydrological processes and the associated erosional responses are known to be related to soil properties (Kinnell and Cummings, 1993). Defersha and Melesse (2012) studied the effects of slope gradient and rainfall intensity on sediment concentration with three soils (Eastern Ethiopia Alemaya Black soil, Regosols and Cambisols). Their results showed that sediment concentration and sediment yield varied with soil type, which had textures ranging from clay to sandy clay loam. Consideration for purple soil showing the overlying soil, underlying rock which is known as "the Geotechnical dual structure", subsurface flow is a prominent runoff process in purple soil slope. However, few studies have focused on this runoff process and the influence of the processes on sediment yielding process. Thus, it is necessary to analyze the hydrological processes and the associated erosional responses on the purple soil slope. We hypothesized that the hydrological processes and the associated erosional responses on the purple soil slope can be described in terms of the combination of rainfall intensity and slope gradient.

The objectives of this study were: (i) to measure and analyze flow hydrodynamic parameter variation under varied slope gradients and rainfall intensities in purple soil; (ii) to investigate the production mechanism of surface flow, subsurface flow and sediment based on rainfall simulations; (iii) to evaluate the relationship between sediment concentration and hydraulic parameters in purple soil. The findings can offer useful data for the building of soil erosion mechanics model in purple soil and present scientific guidance for the construction of soil and water conservation in the Three Gorges Reservoir Area.

\section{MATERIALS AND METHODS Experiment sites and materials}

In this study, the simulated rainfall experiments were conducted on experimental flume at laboratory of soil erosion, Wuhan, China. The selected soils were derived from purple sandy shale, which were the main parent materials in the study watershed and its sand, silt and clay contents were $46 \%, 23 \%$, $31 \%$. Based on the US Soil Taxonomy, they were classified into entisols. The bulk density of packed soil in the flume was $1.35 \mathrm{~g} \cdot \mathrm{cm}^{-3}$. In order to minimize the difference among treatments, soil moisture content was adjusted to $9 \%$ (gravimetrical- ly) for all the treatment plots at the beginning of rain simulation experiments. Pre-wetting took place by applying water through the drain for $24 \mathrm{~h}$.

\section{Rainfall simulation experimental system}

The rainfall simulation experiments were conducted under the laboratory conditions (Fig. 1). The experimental system includes rainfall simulator (a side-sprinkle rainfall simulating set-up), an experimental soil flume (the flume was $3 \mathrm{~m}$ in length, $1 \mathrm{~m}$ in width and $0.5 \mathrm{~m}$ in depth). Slope gradient of the flume can be adjusted in the range of $0-25^{\circ}$. The soil profile at the downslope end of the flume was covered with an aminoplastic web and the gap between the amino-plastic web and the bottom of the flume was filled with gravel (Jia et al., 2007). A trench about $0.05 \mathrm{~m}$ deep and $1 \mathrm{~m}$ width were constructed at the bottom of the flume. Outlet of the trench was connected to a subsurface runoff collection container.

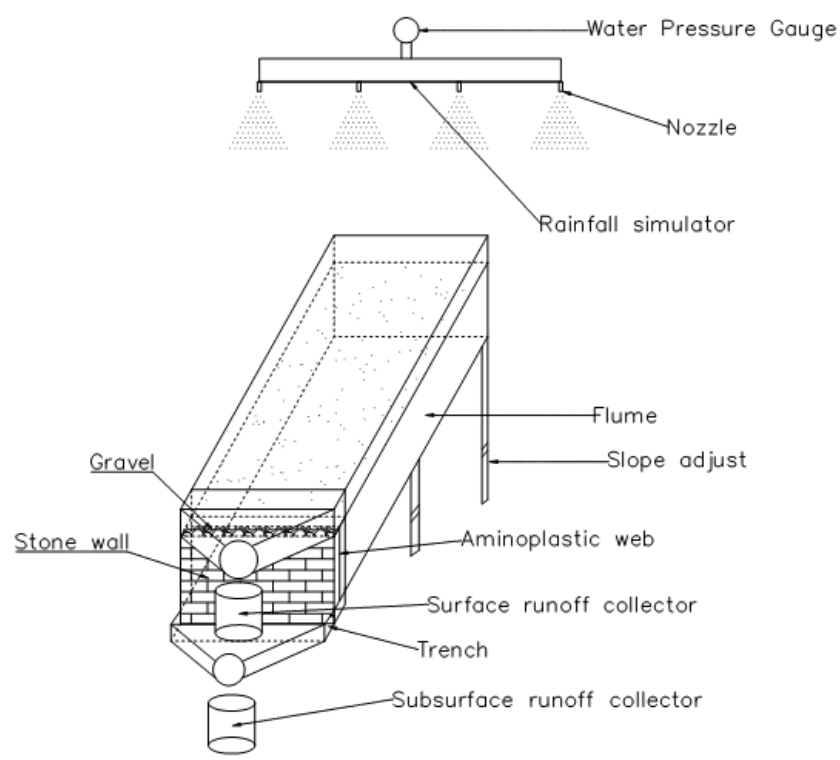

Fig. 1. Rainfall simulation experimental system.

\section{Designs and measurements on rainfall simulation experiments}

Designs and measurements on rainfall simulation experiments were shown in Table 1.

Simulated rainfall was applied with lateral spraying nozzles parallel to the slope. The height of simulated rainfall was $16 \mathrm{~m}$ and the uniformity of simulated storm was more than $85 \%$, which means it was similar to natural rainfall condition. A power-adjusting pump was employed for water supply to the rainfall simulator. Simulated rainfall intensities were generated by adjusting nozzle combination and water pressure. Five types of rain $\left(0.6,1.1,1.61,2.12\right.$ and $\left.2.54 \mathrm{~mm} \cdot \mathrm{min}^{-1}\right)$ were selected, based on the rainfall intensity and frequency of storms in the study area. These rainfall intensities were representatives of the maximum 5-min precipitation $\left(I_{5}\right)$, the maximum 10 -min precipitation $\left(I_{10}\right)$, the maximum 15 -min precipitation $\left(I_{15}\right)$, the maximum 30-min precipitation $\left(I_{30}\right)$, and the maximum $60-\mathrm{min}$ precipitation $\left(I_{60}\right)$ in the Three Gorges Reservoir Area (Wang et al., 2010): approximately $2.54,2.12,1.61,1.1$, and 0.6 $\mathrm{mm} \cdot \mathrm{min}^{-1}$, respectively (the return period is $10 \mathrm{yr}$ ), following a similar method as Shen at al. (2015), since high-intense and 
Hydraulic characteristics and sediment generation on slope erosion in the Three Gorges Reservoir Area, China

Table 1. Chart summarizing design and change characteristics on some hydrodynamic parameters.

\begin{tabular}{|c|c|c|c|c|c|c|c|}
\hline $\begin{array}{c}\text { Slope gradient } \\
\left({ }^{\circ}\right)\end{array}$ & $\begin{array}{l}\text { Simulated rainfall intensity } \\
\qquad\left(\mathrm{mm} \cdot \mathrm{min}^{-1}\right)\end{array}$ & $\begin{array}{c}\text { Flow } \\
\text { velocity } \\
V\left(\mathrm{~m} \cdot \mathrm{s}^{-1}\right)\end{array}$ & $\begin{array}{c}\text { Reynold } \\
\text { number } \\
\text { Re }\end{array}$ & $\begin{array}{c}\text { Froude } \\
\text { number } \\
F r\end{array}$ & $\begin{array}{c}\text { Darcy- } \\
\text { Weisbach } \\
f\end{array}$ & $\begin{array}{l}\text { Manning roughness } \\
n\left(\mathrm{~m}^{-1 / 3} \cdot \mathrm{s}\right)\end{array}$ & $\begin{array}{c}\text { Stream power } \\
w\left(\mathrm{~kg} \cdot \mathrm{s}^{-3}\right)\end{array}$ \\
\hline \multirow{5}{*}{5} & 0.6 & 0.043 & 104.91 & 0.322 & 2.143 & 0.058 & 0.021 \\
\hline & 1.1 & 0.069 & 302.06 & 0.316 & 2.225 & 0.069 & 0.091 \\
\hline & 1.61 & 0.069 & 370.35 & 0.365 & 1.668 & 0.057 & 0.068 \\
\hline & 2.12 & 0.069 & 611.07 & 0.385 & 1.499 & 0.053 & 0.062 \\
\hline & 2.54 & 0.074 & 995.08 & 0.360 & 1.714 & 0.060 & 0.087 \\
\hline \multirow{5}{*}{10} & 0.6 & 0.048 & 195.94 & 0.350 & 3.626 & 0.076 & 0.050 \\
\hline & 1.1 & 0.070 & 387.80 & 0.391 & 2.906 & 0.074 & 0.125 \\
\hline & 1.61 & 0.070 & 612.41 & 0.362 & 3.390 & 0.082 & 0.145 \\
\hline & 2.12 & 0.069 & 994.97 & 0.387 & 2.966 & 0.075 & 0.122 \\
\hline & 2.54 & 0.084 & 1127.17 & 0.436 & 2.337 & 0.068 & 0.173 \\
\hline \multirow{5}{*}{15} & 0.6 & 0.050 & 199.58 & 0.400 & 4.162 & 0.079 & 0.065 \\
\hline & 1.1 & 0.069 & 410.13 & 0.511 & 2.550 & 0.063 & 0.105 \\
\hline & 1.61 & 0.063 & 649.78 & 0.508 & 2.580 & 0.062 & 0.081 \\
\hline & 2.12 & 0.082 & 1158.67 & 0.507 & 2.591 & 0.068 & 0.179 \\
\hline & 2.54 & 0.092 & 1143.45 & 0.529 & 2.380 & 0.066 & 0.232 \\
\hline \multirow{5}{*}{20} & 0.6 & 0.055 & 338.48 & 0.416 & 5.126 & 0.089 & 0.107 \\
\hline & 1.1 & 0.066 & 483.69 & 0.595 & 2.506 & 0.059 & 0.090 \\
\hline & 1.61 & 0.074 & 850.15 & 0.605 & 2.423 & 0.060 & 0.123 \\
\hline & 2.12 & 0.080 & 1138.44 & 0.700 & 1.810 & 0.050 & 0.116 \\
\hline & 2.54 & 0.104 & 1571.67 & 0.733 & 1.651 & 0.052 & 0.232 \\
\hline
\end{tabular}

short-duration rainstorms, which are primarily responsible for soil erosion in the Three Gorges Reservoir Area, China. Four slope gradients $\left(5^{\circ}, 10^{\circ}, 15^{\circ}\right.$ and $\left.20^{\circ}\right)$ were selected, which are representative of main slope gradients in farmland of Wangjiaqiao watershed. A total of 20 treatment combinations were performed. The precipitation for each rainfall event was set to $50 \mathrm{~mm}$. The duration of rainfall was controlled by the precipitation. The duration of rainfall was $83,45,31,24$, and 20 min for rainfall intensities of $0.6,1.1,1.61,2.12$ and $2.54 \mathrm{~mm} \cdot \mathrm{min}^{-1}$, respectively.

Surface flow and subsurface flow were collected in the pail. At the beginning of runoff generation, samples were collected every $2 \mathrm{~min}$. When the flow reached a stable state, the sampling interval was set to $5 \mathrm{~min}$. All treatments were run three times, runoff samples with sediment were settled separated from the water, and then oven-dried at $105^{\circ} \mathrm{C}$ for more than $8 \mathrm{~h}$ to calculate sediment concentration.

\section{Measurements of hydrodynamic parameters}

Surface flow velocities $\left(V_{\mathrm{s}}\right)$ were measured by the dye method. The slope was divided into 3 parts for calculating the flow velocities along the flume length direction with $1 \mathrm{~m}$ interval. The mean surface flow velocities were the average of three measured values. The mean flow velocities $(V)$ was calculated by the relation of $V=n V_{\mathrm{s}}$, where $\mathrm{n}$ is a coefficient, laminar flow, $n$ is 0.67 ; transition flow, $n$ is 0.70 ; turbulent flow, $n$ is 0.80 (Abrahams et al., 1986).

The Reynolds number $(\mathrm{Re})$ and the Froude number $(\mathrm{Fr})$ were calculated from Eqs. (6) and (7), respectively:

$$
\begin{aligned}
& R e=\frac{V h}{v} \\
& F r=\frac{V}{\sqrt{g h}}
\end{aligned}
$$

where, $v$ is kinematic viscosity coefficient $\left(\mathrm{m}^{2} \cdot \mathrm{s}^{-1}\right)$.
One-way ANOVA was used to analyze the difference of runoff and sediment and the least significant difference (LSD) method at the 0.05 probability level was used to identify statistically differ among treatments. The relationships between runoff and sediment were analyzed by a simple regression method. All of these analyses were conducted using SPSS 20.0 software.

\section{RESULTS AND DISCUSSION Flow hydraulic characteristics}

The mean flow velocities were measured during each run. Darcy-Weisbach $(f)$, Manning friction coefficients $(n)$, Reynolds numbers $(R e)$ and Froude numbers $(F r)$, were calculated by Eqs. (2), (3), (6) and (7), respectively, and were listed in Table 1. Flow velocity is a crucial indicator in the study of soil erosion. Foster et al. (1984) concluded that for a non-erodible bed, rill flow velocity increased with slope gradient. In contrast, Govers $(1991,1992)$ found that rill flow velocities were independent of the slope. Nearing et al. $(1997,1999)$ and Giménez and Govers (2001) have confirmed this finding. In this study, the average flow velocities ranged from $0.043 \mathrm{~m} \cdot \mathrm{s}^{-1}$ to 0.104 $\mathrm{m} \cdot \mathrm{s}^{-1}$ at different experimental conditions (Table 1). This implied that the average flow velocities changed either with rainfall intensities and slope gradients. For purple soil, as rainfall intensities increased from 0.6 to $2.54 \mathrm{~mm} \cdot \mathrm{min}^{-1}$, the average flow velocities increased with higher slope gradients, which increased by $72 \%, 75 \%, 84 \%, 89 \%$, respectively, compared to slope gradients at $5^{\circ}, 10^{\circ}, 15^{\circ}$ and $20^{\circ}$ conditions. The cause of this result may be the sine component of gravity increase.

The Reynolds numbers ranged from 104.91 to 1571.67 (Table 1). According to the criterion of open channel flow, surface flow of the slope changed from laminar flow to turbulence flow as rainfall intensities and slope gradients increased in the experiment. The Froude numbers ranged from 0.316 to 0.733 . The values of $F r$ in our study were less than 1, and all of them were subcritical flow. Under the condition of rainfall intensities kept the same, the Froude numbers increased with higher slope gradients, and this relationship became more obvious on steeper slopes. Our results are different with other findings (Guo et al., 2013; Peng et al., 2015; Zhang et al., 2002) which both $R e$ and 
$\mathrm{Fr}$ are greater than our values. The cause of those differences may be explained by the effective input water rate (greater rainfall intensities and slope gradients) and soil type.

Darcy-Weisbach and Manning friction coefficients are the most commonly used parameters to reflect hydraulic resistance in over-land flow studies. Foster et al. (1984) concluded that the resistance coefficient was less than 0.5 at slope gradients of $1.7^{\circ}$ to $5.16^{\circ}$. However, Abrahams et al. (1996) studied rill hydraulics on a semiarid hillslope. They reported that, under the condition of slope gradients kept at $0.74^{\circ}$ to $3.2^{\circ}$, the DarcyWeisbach friction coefficients ranged from 0.2 to 2.84 in wide shallow rills. Moreover, numerous studies (Foster et al., 1984; Savat, 1980; Smith et al., 2007) have reported that flow resistance can be modelled as a function of the Reynolds number and can be expressed as:

$$
f=a e^{-b}
$$

where $a$ and $b$ are regression parameters that are influenced by flow regime and slope gradients.

In this study, the values of $f$ ranged from 1.499 to 5.126. The Darcy-Weisbach friction coefficients and Reynolds numbers were plotted in Figure 2. The Darcy-Weisbach friction coefficients did not show a definitive relationship with Reynolds numbers. Our results agree with other findings (Nearing et al., 1997; Peng et al., 2015; Zhang et al., 2014) which indicated that the Reynolds number was not a good predictor of hydraulic roughness on hillslope. Furthermore, the date from our experiments indicated that the Darcy-Weisbach friction coefficients are primarily influenced by slope gradient.

The Manning roughness coefficients ranged from 0.050 to 0.089 , with an average of 0.066 . As shown in Figure 3, the relationship between Manning roughness coefficients and Reynolds numbers could be expressed as: $n=0.099 R e^{-0.064}$ $\left(R^{2}=0.041\right)$. The results showed that $R e$ may be not applied as an independent hydraulic parameter to measure $n$ effectively.

\section{Rainfall intensity and slope gradient effects on runoff}

Runoff for different slope gradients and simulated rainfall intensities were measured (Figures 4 and 5; Table 2). Average surface runoff volume ranged from 98.03 to $148.64 \mathrm{~L}$, Which was 48.1 to 280.1 times of that for subsurface runoff (Table 2). In addition, surface runoff was markedly different among different slope gradients under the influence of simulated rainfall with intensity of $0.6,1.61,2.12$ and $2.54 \mathrm{~mm} \cdot \mathrm{min}^{-1}$. These results indicated that surface runoff was affected markedly by slope gradients, with the exception of rainfall with intensity of $1.1 \mathrm{~mm} \cdot \mathrm{min}^{-1}$. On the other hand, under conditions of low $(0.6$ $\left.\mathrm{mm} \cdot \mathrm{min}^{-1}\right)$ and high $\left(2.12\right.$ and $\left.2.54 \mathrm{~mm} \cdot \mathrm{min}^{-1}\right)$ rainfall intensities, surface runoff increased with slope gradient increased (Figure 4a). One explanation for this was that infiltration rate decreased with increasing slope gradient (Sharma et al., 1983).

Moreover, an increase in slope gradient enhanced flow velocity and reduced the chance that runoff would be infiltrated into the soils (Fang et al., 2015). Under condition of moderate rainfall intensities $\left(1.1\right.$ and $\left.1.6 \mathrm{~mm} \cdot \mathrm{min}^{-1}\right)$, surface runoff increased with slope gradient when the slope was less than $10^{\circ}$, and this relationship becomes more obvious on steeper slopes $\left(>15^{\circ}\right)$. This may be due to the facts that infiltration decreased greatly with slope gradient when the slope was less than the critical slope (Cheng et al., 2008). Under the condition of slope gradient kept the same, surface runoff increased with rainfall intensity when the simulated rainfall intensity was larger than

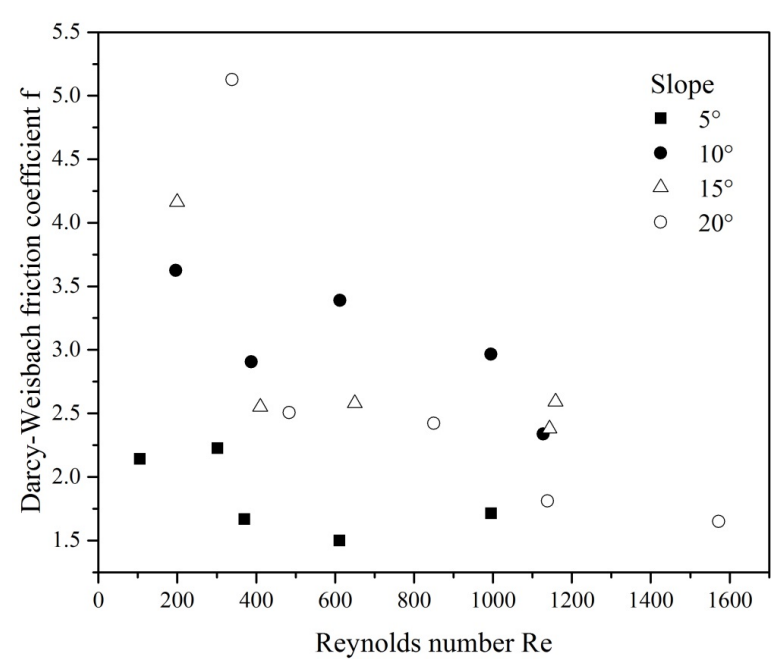

Fig. 2. Relationship between Darcy-Weisbach friction coefficient and Reynolds number.

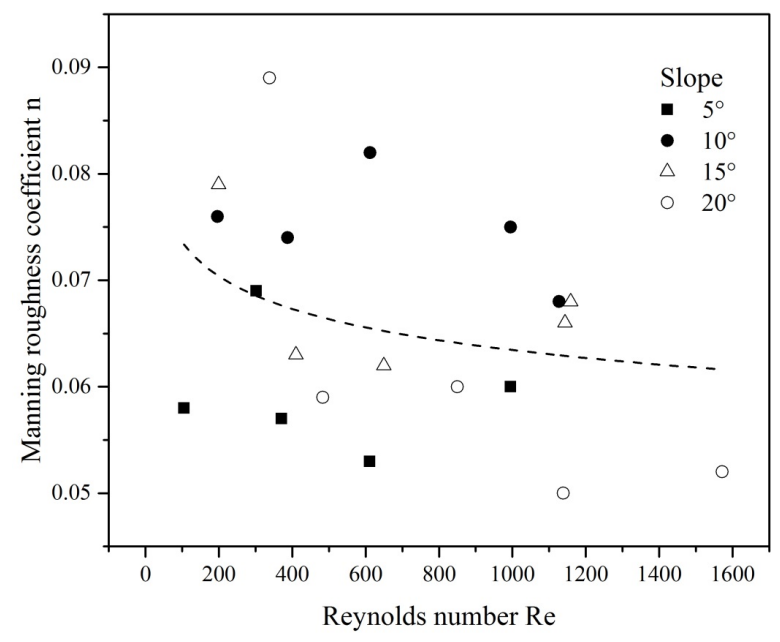

Fig. 3. Relationship between Manning roughness coefficient and Reynolds number.

$1.6 \mathrm{~mm} \cdot \mathrm{min}^{-1}$ (Figure $4 \mathrm{~b}$ ). Our result is consistent with other findings (Ran et al., 2012; Zhao et al., 2015) in rainfall intensity increasing runoff, but surface runoff in our study decreased with rainfall intensity increased when the simulated rainfall intensity was less than $1.6 \mathrm{~mm} \cdot \mathrm{min}^{-1}$ (Figure $4 \mathrm{~b}$ ). This may be associated with a lager infiltration rate of purple soil, lower rainfall intensity with long duration compared to other studies. Defersha and Melesse (2012) and Fang et al. (2015) found that the effects of slope and rainfall intensity on runoff and soil loss varied with soil type. In our experiment, surface runoff showed decreasing-increasing trend as rainfall intensity changed (Figure 4b). This may be associated with the physical properties of purple soil and effects of different rainfall intensity. Moreover, rill erosion occurs as rainfall intensity changed from low to moderate rainfall intensity. Rills increased water infiltration into soil (Sirjacobs et al., 2000). Therefore, surface runoff decreased when the rainfall intensity changed from low to moderate. As rainfall intensity changed from moderate to high rainfall intensity, infiltration excess runoff occurs when rainfall intensity exceeded the infiltration capacity. Consequently, surface runoff increased when the rainfall intensity changed from moderate to high.

Compared with the surface runoff for different slope gradients and simulated rainfall intensities, the subsurface runoff also responded to the slope and rainfall. Average subsurface runoff 


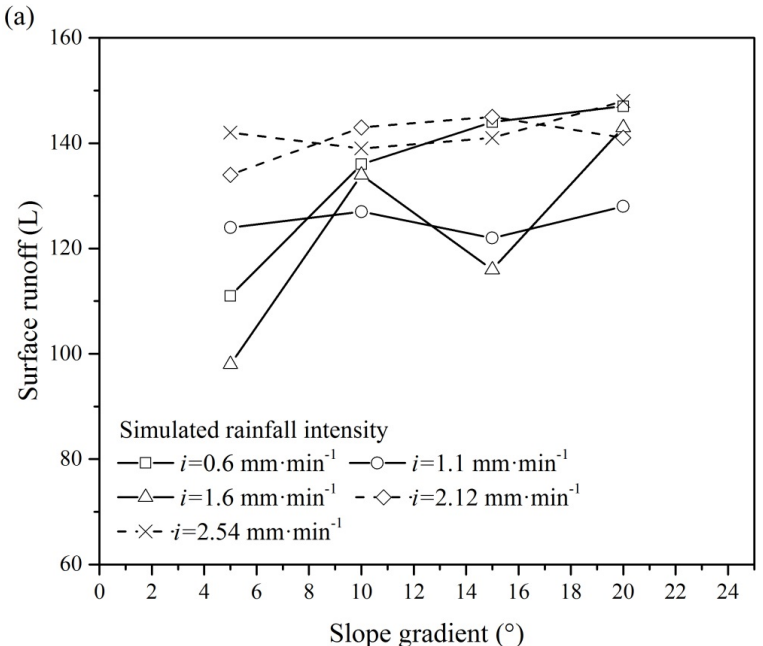

(b)

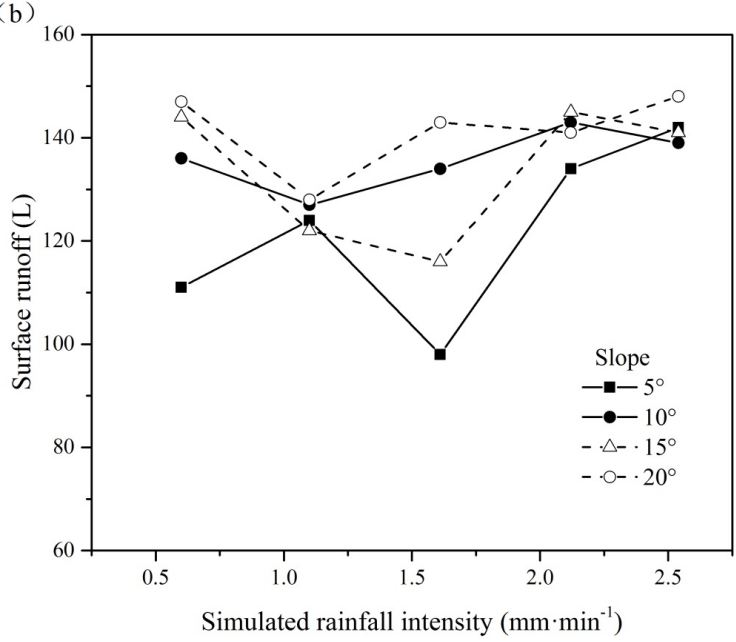

Fig. 4. Surface runoff for different (a) slope gradients and (b) simulated rainfall intensities.
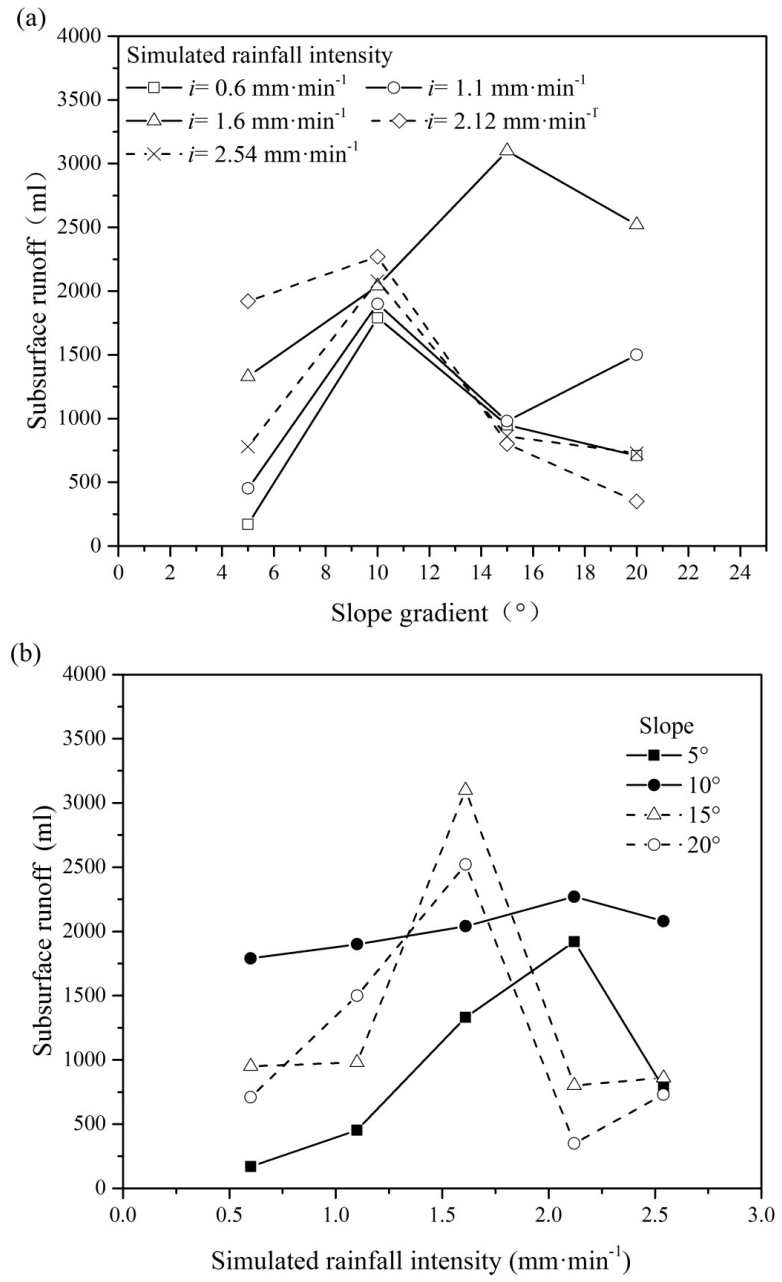

Fig. 5. Subsurface runoff for different (a) slope gradients and (b) simulated rainfall intensities.

Table 2. Average surface runoff and subsurface runoff volume (L) under different rainfall intensities and slope gradients.

\begin{tabular}{|c|c|c|c|c|c|c|}
\hline \multirow{3}{*}{$\begin{array}{l}\text { Runoff } \\
\text { volume } \\
\text { (L) }\end{array}$} & \multirow{3}{*}{$\begin{array}{c}\text { Slope } \\
\text { gradient } \\
\left({ }^{\circ}\right)\end{array}$} & \multicolumn{5}{|c|}{ Rainfall intensity $\left(\mathrm{mm} \cdot \mathrm{min}^{-1}\right)$} \\
\hline & & \multirow{2}{*}{$\begin{array}{c}\text { Low } \\
0.6 \\
\end{array}$} & \multicolumn{2}{|c|}{ Moderate } & \multicolumn{2}{|c|}{ High } \\
\hline & & & 1.1 & 1.61 & 2.12 & 2.54 \\
\hline \multirow{4}{*}{ Surface runoff } & 5 & $110.59 \mathrm{a}$ & $124.06 \mathrm{ab}$ & $98.03 \mathrm{a}$ & $134.07 \mathrm{a}$ & $141.71 \mathrm{~b}$ \\
\hline & 10 & $135.32 b$ & $126.65 \mathrm{ab}$ & $134.40 \mathrm{c}$ & $142.84 b c$ & $139.34 \mathrm{a}$ \\
\hline & 15 & $143.31 \mathrm{bc}$ & $122.36 \mathrm{a}$ & $115.33 b$ & $144.55 \mathrm{c}$ & $141.43 \mathrm{ab}$ \\
\hline & 20 & $147.09 \mathrm{c}$ & $127.45 b$ & $143.20 \mathrm{~d}$ & $141.44 b$ & $148.64 \mathrm{c}$ \\
\hline \multirow{4}{*}{ Subsurface runoff } & 5 & $0.18 \mathrm{a}$ & $0.46 \mathrm{a}$ & $1.35 \mathrm{a}$ & $1.93 \mathrm{c}$ & $0.77 \mathrm{~b}$ \\
\hline & 10 & $1.80 \mathrm{~d}$ & $1.91 \mathrm{~d}$ & $2.07 \mathrm{~b}$ & $2.27 \mathrm{~d}$ & $2.08 \mathrm{~d}$ \\
\hline & 15 & $0.94 \mathrm{c}$ & $0.98 b$ & $3.09 \mathrm{~d}$ & $0.80 \mathrm{~b}$ & $0.85 \mathrm{c}$ \\
\hline & 20 & $0.72 b$ & $1.51 \mathrm{c}$ & $2.53 \mathrm{c}$ & $0.35 \mathrm{a}$ & $0.74 \mathrm{a}$ \\
\hline
\end{tabular}

Note: Means within a column followed by the different letters are significantly different at $\mathrm{p}=0.05$ level using the least significant difference (LSD) method.

volume ranged from 0.35 to $3.09 \mathrm{~L}$ (Table 2). Under the condition of rainfall intensity kept the same, the influence of slope gradient on subsurface runoff was significant. For the same level of rainfall intensity, subsurface runoff increased at first, then decreased with slope gradient increased (Figure 5a). The subsurface runoff reached the maximum for most rainfall intensities when the slope gradient increased from $5^{\circ}$ to $10^{\circ}$, but when rainfall intensity was $1.6 \mathrm{~mm} \cdot \mathrm{min}^{-1}$, the slope gradient was $15^{\circ}$. Under the condition of slope gradient kept the same, subsurface runoff increased at first, then decreased with rainfall intensity increased (Figure 5b). This may be due to the facts that a long low intensity rainfall can cause more subsurface flow than a short high intensity rainfall (Jia et al., 2007; Naef et al., 2002). On a slope less than $10^{\circ}$, subsurface runoff reached the maximum when rainfall intensity was $2.1 \mathrm{~mm} \cdot \mathrm{min}^{-1}$. However, on steeper slopes ranged from $15^{\circ}$ to $20^{\circ}$, subsurface runoff reached the maximum when rainfall intensity was 1.6 $\mathrm{mm} \cdot \mathrm{min}^{-1}$. Our results indicated that there existed a critical slope of the purple soil slope, which was about $10^{\circ}$. This finding was similar with Jin (1996) who found the infiltration rates showed an increasing-decreasing trend as slope gradient changed. Infiltration decreased greatly with slope gradient when the slope was larger than the critical slope gradient. This may be due to the facts that soil surface seal formation processes reduce the infiltration rates (Assouline and Ben-Hur, 2006; Luk et al., 1993). 


\section{Sediment}

The average sediment yield rate, which we defined as the average rate of sediment loss during the period when there was surface runoff in the storm. It ranged from 4.01 to 172.39 $\mathrm{g} \cdot \mathrm{m}^{-2} \cdot \mathrm{min}^{-1}$. There was significant statistical difference in the sediment yield rate among different slope gradients (Table 3 ). Sediment yield rates increased with increases in both rainfall intensity and slope gradient (Figure 6). This pattern accorded with other studies (Defersha and Melesse, 2012; Wang et al., 2015; Zhang et al., 2002) in slope gradient and flow discharge increasing sediment yield rate. Under conditions of low (0.6 $\left.\mathrm{mm} \cdot \mathrm{min}^{-1}\right)$ and moderate $\left(1.1\right.$ and $\left.1.61 \mathrm{~mm} \cdot \mathrm{min}^{-1}\right)$ and high (2.12 and $\left.2.54 \mathrm{~mm} \cdot \mathrm{min}^{-1}\right)$ rainfall intensities, the sediment yield rates increased by 3.95, 2.39, 5.04, 3.48, 3.99 times, respectively, as the slope gradients increased from $5^{\circ}$ to $20^{\circ}$. On the other hand, for the slope gradients of $5^{\circ}, 10^{\circ}, 15^{\circ}$ and $20^{\circ}$, the sediment yield rates increased by $10.75,6.59,9.31,10.90$ times, respectively, as the rainfall intensities increased from 0.6 to $2.54 \mathrm{~mm} \cdot \mathrm{min}^{-1}$. This result showed that sediment yield rate was more sensitive to rainfall intensity changes than to slope gradient changes. Similarly, Ziadat and Taimeh (2013) reported that rainfall intensity was the most important factor affecting soil erosion among rainfall intensity, slope gradient, land use and antecedent soil moisture. However, this result disagreed with Liu et al. (2015), who found that the sediment loss rate was more sensitive to changes in slope gradient than to changes in the rainfall intensity. This may be associated with the difference in soil type, simulated rainfall intensity and slope gradient.
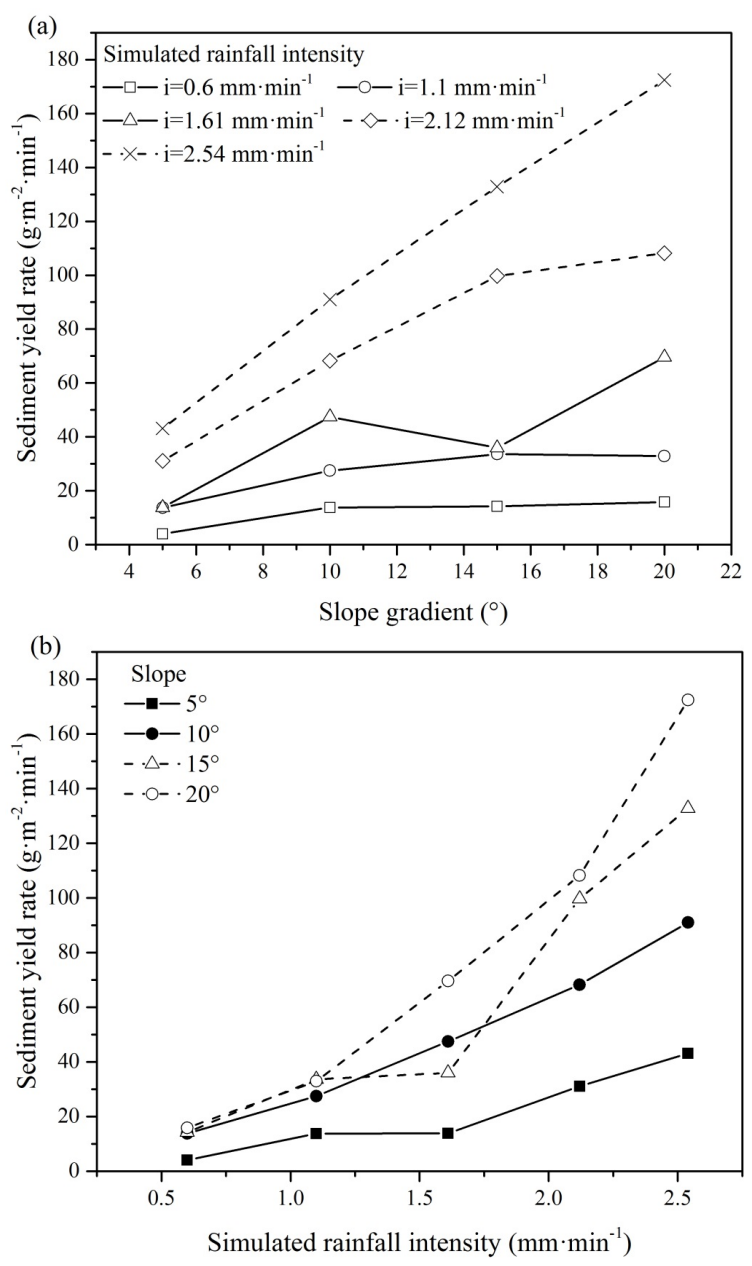

Fig. 6. Sediment yield rate for different (a) slope gradients and (b) simulated rainfall intensities.
Table 3. Average sediment yield rate $\left(\mathrm{g} \cdot \mathrm{m}^{-2} \cdot \mathrm{min}^{-1}\right)$ under different rainfall intensities and slope gradients.

\begin{tabular}{cccccc}
\hline Slope & \multicolumn{5}{c}{ Rainfall intensity $\left(\mathrm{mm} \cdot \mathrm{min}^{-1}\right)$} \\
\cline { 2 - 6 } gradient & Low & \multicolumn{2}{c}{ Moderate } & \multicolumn{2}{c}{ High } \\
\cline { 2 - 6 }$\left({ }^{\circ}\right)$ & 0.6 & 1.1 & 1.61 & 2.12 & 2.54 \\
\hline 5 & $4.01 \mathrm{a}$ & $13.75 \mathrm{a}$ & $13.81 \mathrm{a}$ & $31.10 \mathrm{a}$ & $43.12 \mathrm{a}$ \\
10 & $13.80 \mathrm{~b}$ & $27.50 \mathrm{~b}$ & $47.42 \mathrm{c}$ & $68.26 \mathrm{~b}$ & $91.01 \mathrm{~b}$ \\
15 & $14.27 \mathrm{c}$ & $33.63 \mathrm{~d}$ & $36.00 \mathrm{~b}$ & $99.69 \mathrm{c}$ & $132.83 \mathrm{c}$ \\
20 & $15.82 \mathrm{~d}$ & $32.90 \mathrm{c}$ & $69.60 \mathrm{~d}$ & $108.23 \mathrm{~d}$ & $172.39 \mathrm{~d}$ \\
\hline
\end{tabular}

Note: Means within a column followed by the different letters are significantly different at $p=0.05$ level using the least significant difference (LSD) method.

\section{Modeling soil loss}

Soil erosion is a process of detachment and transportation of soil materials by erosive agents (Ellison, 1947). Many studies have reported the slope characteristics (such as soil type, slope gradient and soil surface roughness) and flow hydraulics (such as flow velocity, flow depth and hydraulic roughness) are the two major controlling factors of slope soil loss (EI Kateb et al., 2013; Fox and Bryan, 2000; Gilley et al., 1985; Guo et al., 2013; Mathier et al., 1989). Therefore, the main hydraulic indicators were selected to use for soil loss modeling. In order to compare those parameters, relationships between the average sediment yield rate $(S r)$, Reynolds numbers $(R e)$, Froude numbers $(F r)$, Darcy-Weisbach $(f)$, Manning friction coefficients $(n)$, flow velocity $(v)$ and stream power $(w)$ were shown in Fig. 7. As is shown, the sediment yield rate had positive relationships with Reynolds numbers, Froude numbers, flow velocity and stream power and negative relationships with DarcyWeisbach $(f)$ and Manning friction coefficients. Also, our results indicated that among those hydraulic parameters, just Reynolds numbers $\left(R^{2}=0.871\right)$, flow velocity $\left(R^{2}=0.783\right)$ and stream power $\left(R^{2}=0.884\right)$ showed a good linear relationship with sediment yield rate, whereas $F r, f$ and $n$ were not good hydraulic indicators for the sediment yield rate in flume experiment. Among those hydraulic parameters, stream power showed the best performance in predicting soil concentration, followed by Reynolds numbers and flow velocity. This finding revealed that for purple soil at the small scale of flume, stream power could be used for modeling purple soil loss. Similarly, Cao et al. (2013) found a significant linear relationship between soil loss and stream power. In most process-based erosion models, stream power have been used for predicting soil detachment (Hairsine and Rose, 1992; Nearing et al., 1997). Stream power can be used to illustrate the effect of both the slope gradient and runoff rate during soil loss (Huang, 1995). As mentioned previously, the slope gradient and rainfall intensity were recognized as the main controlling factors of slope soil erosion. Thus, the combination of slope gradient and rainfall intensity affected sediment yield rate. As mentioned previously, stream power was best correlated to soil loss, but it cannot be applied to describe the effect of both the slope gradient and rainfall intensity. Researchers have quantified the power regression relationship between soil loss, runoff rate, slope gradient and rainfall intensity (Bulygin et al., 2002; Kinnell, 1993; Zhang et al., 1998). Therefore, we used the following equation to assess the quantifiable relationship between the sediment yield rates, runoff rates, slope gradients and rainfall intensities.

$$
S r=k I Q^{a} S^{b}
$$



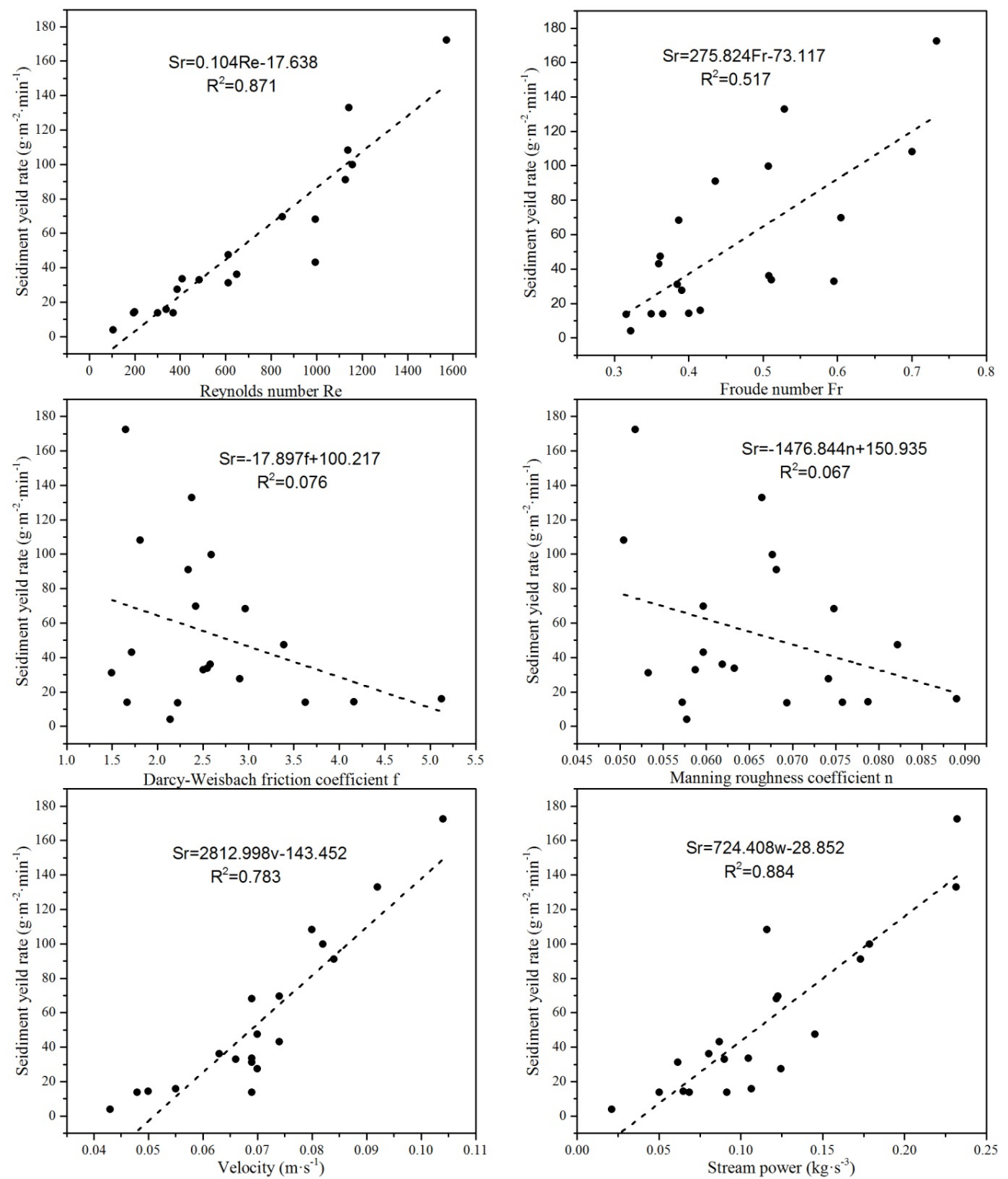

Fig. 7. Relationships between the sediment yield rate ( $\mathrm{Sr})$ and hydraulic parameter.

where, $S r$ is the sediment yield rate $\left(\mathrm{g} \cdot \mathrm{m}^{-2} \cdot \mathrm{min}^{-1}\right), I$ is the rainfall intensity $\left(\mathrm{mm} \cdot \mathrm{min}^{-1}\right), Q$ is the runoff rate $\left(\mathrm{mm} \cdot \mathrm{min}^{-1}\right), k, a$ and $b$ are regression parameters. The corresponding regression equation was derived:

$$
S r=250.385 I Q^{0.558} S^{0.869}\left(R^{2}=0.897\right) .
$$

As shown in Fig. 8, this model can provide an estimation of soil loss which is based on the interaction of rainfall intensity, runoff rate and slope gradient and close to the 1:1 line. Meanwhile, among the models, Eq. (10) was the most effective in predicting purple soil loss. The better performance of Eq. (10) over the other hydraulic parameters indicated that rainfall intensity is one of the most significant factors affecting purple soil erosion.

\section{CONCLUSIONS}

This study investigated the hydraulic characteristics and sediment generation on purple soil erosion within the rainfall simulation system at various rainfall intensities and slope gradients.

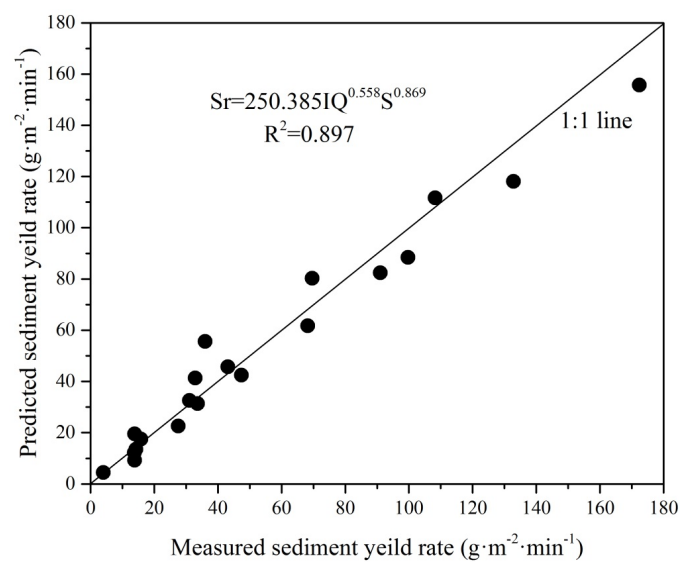

Fig. 8. Comparison between measured and predicted sediment yield rate.

The results showed that surface and subsurface runoff were influenced by both the rainfall intensity and slope gradient. There existed a critical slope of the purple soil slope, which was about $10^{\circ}$. Subsurface runoff increased with slope to a maxi- 
mum level when the slope was larger than $10^{\circ}$ and then decreased. Surface runoff volume ranged from 98.03 to $148.64 \mathrm{~L}$, which was 48.1 to 280.1 times of that for subsurface runoff. Surface flow of the slope changed from laminar flow to turbulence flow as rainfall intensities and slope gradients increased.

Sediment yield rates increased with increases in both rainfall intensities and slope gradients; however, it was more sensitive to rainfall intensity than to slope gradient. In addition, Reynolds numbers $(R e)$, flow velocity $(v)$ and stream power $(w)$ showed a good linear relationship with sediment yield rate, whereas $F r, f$ and $n$ were not good hydraulic indicators for the sediment yield rate on purple soil erosion. Also, stream power $\left(R^{2}=0.884\right)$ showed the best performance in predicting sediment yield rate, followed by Reynolds numbers $\left(R^{2}=0.871\right)$ and flow velocity $\left(R^{2}=0.783\right)$. Based on the power regression relationship between soil loss, runoff rate, slope gradient and rainfall intensity, an erosion model was proposed to predict the purple soil erosion $\left(R^{2}=0.897\right)$. The results can be used to improve the accuracy of models that predict slope erosion in the Three Gorges Reservoir Area, China.

Acknowledgements. Special thanks should be given to all of the crew members in Zigui County Water Resources Bureau. Funding for this research was provided by the Basic Research Fund for Central Public Research Institutes (No. CKSF2014026/TB) and the National Natural Science Foundation of China (No.40901135).

\section{REFERENCES}

Abrahams, A.D., Parsons, A.J., Luk, S.H., 1986. Field measurement of the velocity of overland flow using dye tracing. Earth Surf. Process. Landf., 11, 653-657.

Abrahams, A.D., Li, G., Parsons, A.J., 1996. Rill hydraulics on a semiarid hillslope, Southern Arizona. Earth Surf. Process. Landf., 21, 35-47.

Assouline, S., Ben-Hur, M., 2006. Effects of rainfall intensity and slope gradient on the dynamics of interrill erosion during soil surface sealing. Catena, 66, 211-220.

Berger, C., Schulze, M., Rieke-Zapp, D., Schlunegger, F., 2010. Rill development and soil erosion: a laboratory study of slope and rainfall intensity. Earth Surf. Process. Landf., 35, 1456-1467.

Bulygin, S.Y., Nearing, M.A., Achasov, A.B., 2002. Parameters of interrill erodibility in the WEPP model. Eurasion Soil Sci., 35, 1237-1242.

Cerdà, A., 1998. Relationship between climate and soil hydrological and erosional characteristics along climatic gradients in Mediterranean limestone areas. Geomorphology, 25, 123-124.

Cerdà, A., Giménez-Morera, A., Bodí, M.B., 2009. Soil and water losses from new citrus orchards growing on sloped soils in the western Mediterranean basin. Earth Surf. Process. Landf., 34, 1822-1830.

Cao, L.X., Zhang, K.L., Dai, H.L., Liang, Y., 2015. Modeling interrill erosion on unpaved roads in the Loess Plateau of China. Land Degrad. Dev., 26, 8, 825-832.

Cheng, Q., Ma, W., Cai, Q., 2008. The relative importance of soil crust and slope angle in runoff and soil loss: a case study in the hilly areas of the Loess Plateau, North China. GeoJournal, 71, 117-125.

De Roo, A.P.J., Wesseling, C.G., Cremers, N.H.D.T., Offermans, R.J.E., Ritsema, C.J., Van Oostindie, K., 1994. LISEM: a new physically-based hydrological and soil erosion model in a GIS-environment, theory and implementation. IAHS Publications - Series of Proceedings and Reports
- International Association of the Hydrological Sciences, vol. 224, pp. 439-448.

Defersha, M.B., Melesse, A.M., 2012. Effect of rainfall intensity, slope and antecedent moisture content on sediment concentration and sediment enrichment ratio. Catena, 90, 47-52.

Donjadee, S., Chinnarasri, C., 2012. Effects of rainfall intensity and slope gradient on the application of vetiver grass mulch in soil and water conservation. Int. J. Sed. Res., 27, 168-177.

EI Kateb, H., Zhang, H., Zhang, P., Mosandl, R., 2013. Soil erosion and surface runoff on different vegetation covers and slope gradients: A field experiment in Southern Shaanxi Province, China. Catena, 105, 1-10.

Ellison, W.D., 1947. Soil erosion studies part VI: Soil detachment by surface flow. Agr. Eng., 28, 402-408.

Fang, H., Sun, L., Tang, Z., 2015. Effects of rainfall and slope on runoff, soil erosion and rill development: an experimental study using two loess soils. Hydrol. Process., 29, 11, 26492658.

Foster, G.R., Huggins, L., Meyer, L.D., 1984. A laboratory study of rill hydraulics: I. Velocity relationships. Trans. ASAE, 27, 790-796.

Foster, G.R., Flanagan, D.C., Nearing, M.A., Lane, L.J., Risse, L.M., Finkner, S.C., 1995. Water Erosion Prediction Project (WEPP). Technical documentation. NSERL Report No. 10. National Soil Erosion Research Laboratory. USDA-ARS. West Lafayette, IN 47907-1196.

Fox, D.M., Bryan, R.B., 2000. The relationship of soil loss by interrill erosion to slope gradient. Catena, 38, 211-222.

Fox, D.M., Bryan, R.B., Price, A.G., 1997. The influence of slope angle on final infiltration rate for interrill conditions. Geoderma, 80, 1-2, 181-194.

Fu, Z.Y., Li, Z.X., Cai, C.F., Shi, Z.H., Xu, Q.X., Wang, X.Y., 2011. Soil thickness effect on hydrological and erosion characteristics under sloping lands: a hydropedological perspective. Geoderma, 167-168, 41-53.

Gilley, J.E., Woolhiser, D.A., McWhorter, D.B., 1985. Interrill soil erosion, Part I. Development of model equations. Trans. ASAE, 28, 147-153.

Giménez, R., Govers, G., 2001. Interaction between bed roughness and flow hydraulics in eroding rills. Water Resour. Res., 37, 791-799.

Govers, G., 1991. Time dependency of runoff velocity and erosion: the effect of the initial soil moisture profile. Earth Surf. Process. Landf., 16, 713-729.

Govers, G., 1992. Relationship between discharge, velocity and flow area for rills eroding loose, non-layered materials. Earth Surf. Process. Landf., 17, 515-528.

Guo, T.L., Wang, Q.J., Li, D.Q., Zhuang, J., Wu, L.S., 2013. Flow hydraulic characteristic effect on sediment and solute transport on slope erosion. Catena, 107, 145-153.

Hairsine, P.B., Rose, C.W., 1992. Modeling water erosion due to overland flow using physical principles, 1. Sheet flow. Water Resour. Res., 28, 237-243.

Huang, C.H., 1995. Empirical analysis of slope and runoff for sediment delivery from interrill areas. Soil Sci. Soc. Am. J., 59, 982-990.

Jia, H.Y., Lei, A.L., Lei, J.S., Ye, M., 2007. Effects of hydrological processes on nitrogen loss in purple soil. Agric Water Manag, 89, 89-97.

Jin, C.X., 1996. The role of slope gradient on slope erosion. Geographical Research, 15, 57-62. (In Chinese.)

Julien, P.Y., Simmons, D.B., 1985. Sediment transport capacity of overland flow. Am. Soc. Agric. Eng., 28, 755-762.

Kinnell, P.I.A., 1993. Interrill erodibilities based on the rainfall intensity-flow discharge erosivity factor. Aust. J. Soil Res., 
31, 319-332.

Kinnell, P.I.A., Cummings, D., 1993. Soil slope gradient interactions in erosion by rainimpacted flow. Trans. ASAE, 36, 381-387.

Knapen, A., Poesen, J., Govers, G., De Baets, S., 2008. The effect of conservation tillage on runoff erosivity and soil erodibility during concentrated flow. Hydrol. Process., 22, 1497-1508.

Li, Z.B., Qin, B.S., Kang, W., Li, W., Wei, X., 2008. Indoor experimental studies on hydrodynamic characteristics of runoff in rill erosion procession steep slope. Trans. CSAE, 24, 64-68. (In Chinese.)

Liu, D.D., She, D.L., Yu, S.E., Shao, G.C., Chen, D., 2015. Rainfall intensity and slope gradient effects on sediment losses and splash from a saline-sodic soil under coastal reclamation. Catena, 128, 54-62.

Luk, S.H., Cai, Q.G., Wang, G.P., 1993. Effects of surface crusting and slope gradient on soil and water losses in the hilly loess region, North China. Catena, 24, 29-45.

Mathier, L., Roy, A.G., Paré, J.P., 1989. The effect of slope gradient and length on the parameters of a sediment transport equation for sheetwash. Catena, 16, 545-558.

Morgan, R.P.C., Quinton, J.N., Smith, R.E., Govers, G., Poesen, J.W.A., Auerswald, K., Chisci, G., Torri, D., Styczen, M.E., 1998. The European soil erosion model (EUROSEM): a process-based approach for predicting soil loss from fields and small catchments. Earth Surf. Process. Landf., 23, 527-544.

Nash, D., Halliwell, D., Cox, J., 2002. Hydrological mobilization of pollutants at the field/slope scale. In: Haygarth, P.M., Jarvis, S.C. (Eds.): Agriculture, hydrology and water quality. CAB Int., Wallingford, Oxon, UK, pp. 225-242.

Nearing, M.A., Parker, S.C., 1994. Detachment of soil by flowing water under turbulent and laminar conditions. Soil Sci. Soc. Am. J., 58, 1612-1614.

Nearing, M.A., Norton, L.D., Bulgakov, D.A., Larionov, G.A., West, L.T., Dontsova, K.M., 1997. Hydraulics and erosion in eroding rills. Water Resour. Res., 33, 865-876.

Nearing, M.A., Simanton, J.R., Norton, L.D., Bulygin, S.J., Stone, J., 1999. Soil erosion by surface water flow on a stony, semiarid hillslope. Earth Surf. Process. Landf., 24, 677-686.

Peng, X.D., Shi, D.M., Jiang, D., Wang, S.S., Li, Y.X., 2014. Runoff erosion process on different underlying surfaces from disturbed soils in the Three Gorges Reservoir Area, China. Catena, 123, 215-224.

Peng, W.Y., Zhang, Z.D., Zhang, K.L., 2015. Hydrodynamic characteristics of rill flow on steep slopes. Hydrol. Process. 29, 3677-3686.

Rafael, G., Gerard, G., 2008. Effects of freshly incorporated straw residue on rill erosion and hydraulics. Catena, 72, 214-223.

Ran, Q., Su, D., Li, P., He, Z., 2012. Experimental study of the impact of rainfall characteristics on runoff generation and soil erosion. J. Hydrol., 424, 99-111.
Savat, J., 1980. Resistance to flow in rough supercritical sheet flow. Earth Surf. Process. Landf., 16, 103-122.

Sharma, K., Singh, H., Pareek, O., 1983. Rainwater infiltration into a bare loamy sand. Hydrol. Sci. J., 28, 417-424.

Shen, H.O., Zheng, F.L., Wen, L.L., Jiang, Y.L., Lu, J., 2015. Effects of Rainfall Intensity and Slope Gradient on Rill Morphological Characteristics. Transactions of the Chinese Society for Agricultural Machinery, 46, 8, 104-112. (In Chinese.)

Sirjacobs, D., Shainberg, I., Rapp, I., Levy, G.J., 2000. Polyacrylamide, sediment, and interrupted flow effects on rill erosion and intake rate. Soil Science Society of American Journal, 64, 1487-1495.

Smith, M.W., Cox, N.J., Bracken, L.J., 2007. Applying flow resistance equations to overland flows. Prog. Phys. Geog., 31, 363-387.

Wang, H.J., Zhang, J., Wang, H.J., Tu, S.Y., 2010. The Characteristics of Short-duration Precipitation Extremes of Badong and Yichang Stations in the Yangtze Three Gorges Area. Torrential rain and disasters., 29, 1, 38-43. (In Chinese.)

Wang, Z., Yang, X., Liu, J., Yuan, Y., 2015. Sediment transport capacity and its response to hydraulic parameters in experimental rill flow on steep slope. J. Soil Water Conserv., 70, 36-44.

Wen, A.B., Qi, Y.Q., Wang, Y.C., He, X.B., Fu, J.X., Zhang, X.B., 2005. Study on erosion and sedimentation in Yangtze Three Gorge Region. J. Soil Water Conserv., 19, 2, 33-36. (In Chinese.)

Zhang, X.C., Nearing, M.A., Miller, W.P., Norton, L.D., West, L.T., 1998. Modeling interrill sediment delivery. Soil Sci. Soc. Am. J., 62, 438-444.

Zhang, G.H., Liu, B.Y., Nearing, M.A., Huang, C.H., Zhang, K.L., 2002. Soil detachment by shallow flow. Trans. ASAE, 45, 351-357.

Zhang, G.H., Liu, B.Y., Liu, G.B., He, X.W., Nearing, M.A., 2003. Detachment of undisturbed soil by shallow flow. Soil Sci. Soc. Am. J., 67, 713-719.

Zhang, G.S., Chan, K.Y., Oates, A., Heenan, D.P., Huang, G.B., 2007. Relationship between soil structure and runoff/soil loss after 24 years of conservation tillage. Soil Till. Res., 92, 122-128.

Zhang, G.H., Liu, G.B., Yi, L., Zhang, P.C., 2014. Effects of patterned Artemisia capillaris on overland flow resistance under varied rainfall intensities in the Loess Plateau of China. J. Hydrol. Hydromech., 62, 334-342.

Zhao, Q.H., Li, D.Q., Zhuo, M.N., Guo, T.L., Liao, Y.S., Xie, Z.Y., 2015. Stochastic Environ. Res. Risk Assess., 29, 609621.

Ziadat, F.M., Taimeh, A.Y., 2013. Effect of rainfall intensity, slope and land use and antecedent soil moisture on soil erosion in an arid environment. Land Degrad. Dev. 24, 582590.

Received 8 October 2015 Accepted 9 May 2016 